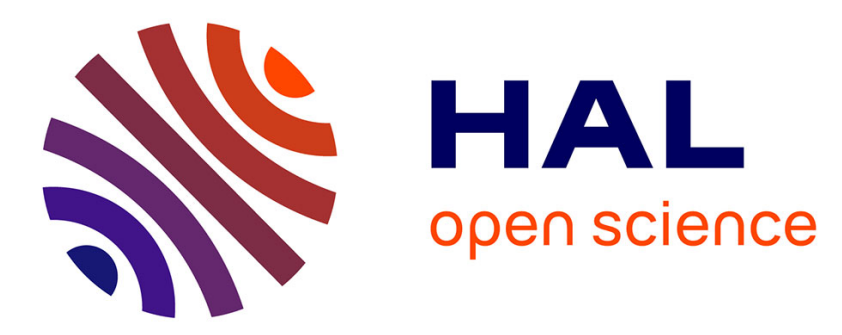

\title{
Restricted ranges in physical factors may constitute subtle stressors for estuarine biota
}

Megan N. Dethier, Jennifer Ruesink, Helen Berry, Amy G. Sprenger, Blain Reeves

\section{- To cite this version:}

Megan N. Dethier, Jennifer Ruesink, Helen Berry, Amy G. Sprenger, Blain Reeves. Restricted ranges in physical factors may constitute subtle stressors for estuarine biota. Marine Environmental Research, 2010, 69 (4), pp.240. 10.1016/j.marenvres.2009.10.015 . hal-00564781

\section{HAL Id: hal-00564781 \\ https://hal.science/hal-00564781}

Submitted on 10 Feb 2011

HAL is a multi-disciplinary open access archive for the deposit and dissemination of scientific research documents, whether they are published or not. The documents may come from teaching and research institutions in France or abroad, or from public or private research centers.
L'archive ouverte pluridisciplinaire HAL, est destinée au dépôt et à la diffusion de documents scientifiques de niveau recherche, publiés ou non, émanant des établissements d'enseignement et de recherche français ou étrangers, des laboratoires publics ou privés. 


\section{Accepted Manuscript}

Restricted ranges in physical factors may constitute subtle stressors for estuarine biota

Megan N. Dethier, Jennifer Ruesink, Helen Berry, Amy G. Sprenger, Blain

Reeves

PII:

S0141-1136(09)00141-X

DOI:

10.1016/j.marenvres.2009.10.015

Reference:

MERE 3390

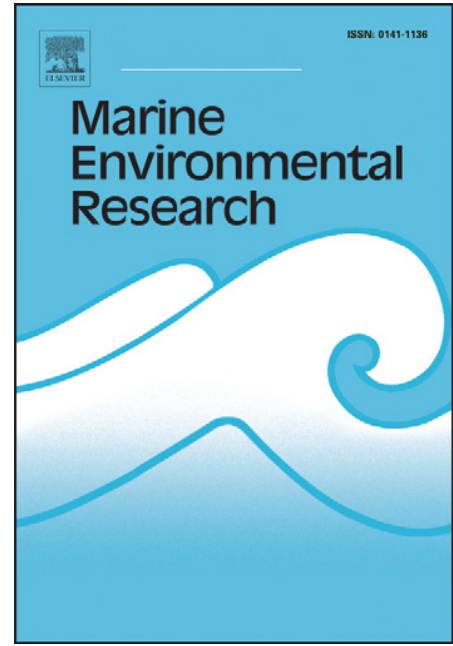

To appear in:

Marine Environmental Research

Received Date:

26 August 2008

Revised Date:

4 September 2009

Accepted Date:

16 October 2009

Please cite this article as: Dethier, M.N., Ruesink, J., Berry, H., Sprenger, A.G., Reeves, B., Restricted ranges in physical factors may constitute subtle stressors for estuarine biota, Marine Environmental Research (2009), doi: 10.1016/j.marenvres.2009.10.015

This is a PDF file of an unedited manuscript that has been accepted for publication. As a service to our customers we are providing this early version of the manuscript. The manuscript will undergo copyediting, typesetting, and review of the resulting proof before it is published in its final form. Please note that during the production process errors may be discovered which could affect the content, and all legal disclaimers that apply to the journal pertain. 
M.N. Dethier et al.

Gradients on an estuarine shoreline

\author{
Restricted ranges in physical factors \\ may constitute subtle stressors for estuarine biota
}

Megan N. Dethier*

Biology Dept and Friday Harbor Labs, University of Washington, Friday Harbor, WA. 98250. Tel: (206) 543-8096, Fax: 206-543-1273, email:

mdethier@u.washington.edu

Jennifer Ruesink

Biology Dept, University of Washington, Seattle, WA. 98195

Helen Berry

Washington Dept. of Natural Resources, Olympia, WA. 98504

Amy G. Sprenger

Biology Dept and Friday Harbor Labs, University of Washington, Friday Harbor,

WA. 98250

Blain Reeves

Washington Dept. of Natural Resources, Olympia, WA. 98504

* Corresponding author. email: mdethier@u.washington.edu

Keywords: estuary, gradient, species richness, biomass, temperature stress, salinity variation 


\begin{abstract}
Biotic trends along estuarine gradients can be affected by co-varying processes ranging from large-scale oceanographic to local-scale physico-chemical effects. As a baseline for future process studies, we investigated the distinct gradients in species richness and biomass in pebblesand shorelines along the estuarine axis of Puget Sound, and the scales of variation of some of their physical correlates. Higher richness and biomass at beaches at the more marine end of the Sound are temporally consistent and seen in all trophic groups. Variables that correlate with biotic patterns include relatively subtle increases in beach surface and sediment temperatures and decreases in nearshore salinity near the head of the estuary, but not more localized parameters such as sediment grain size or porewater salinity. To understand whether these variables are true forcing functions of community structure, we are performing experimental work.
\end{abstract}




\section{INTRODUCTION}

Biodiversity in marine habitats is affected by oceanographic and biogeographic context, local physical gradients, propagule supply, and post-recruitment biotic interactions (Hawkins, 2004). In estuaries, physical gradients often covary with anthropogenic stressors such as pollutants, acting synergistically or antagonistically to impact biodiversity and, subsequently, ecosystem function (Raffaelli, 2006; Rakocinski et al., 2000). The key physical gradients that frequently correlate with estuarine biota are salinity (Giberto et al., 2004; Hirst, 2004; Rutger and Wing, 2006), sediment grain size and deposition rate (Anderson et al., 2004; Hernandez-Arana et al., 2003; Hewitt et al., 2005; Wieser, 1959) and oxygen content (e.g., Bishop et al. 2006). The physiological and ecological effects of particular physical factors, and in some cases their interactions, are known for some estuarine species; salinity has been particularly well studied (reviewed by Wolff 1983, Attrill 2002). The key parameter stressing or excluding species from parts of estuaries may not be absolute ranges (e.g. annual salinity range) but scales of local temporal variation; predictability or 'return time' from extreme events may have a greater ecological impact than seasonal changes, even if the latter are large, because seasonal acclimation is common (Hirst and Kilpatrick, 2007; McLeod and Wing, 2008).

Biotic diversity predictably declines from the outer towards the inner portions of estuaries (Attrill 2002, Dethier and Schoch 2005 and refs. therein, Rutger and Wing 2006) but because of the problem of co-variance of many estuarine gradients, determination of key forcing processes has been elusive. The diversity pattern holds in both pristine and anthropogenically impacted estuaries, suggesting that natural physical gradients may be critical. Primary productivity often positively affects diversity (e.g., Mittlebach et al. 2003), but is complex in estuaries. Consumers may use phytoplankton, macroalgae, or particulate carbon sources; these are affected to varying 
Assessing factors controlling species diversity and biomass in estuaries thus must involve an attempt to decouple large numbers of physical and food-web parameters. Research must occur at a large enough spatial scale to encompass some of these gradients, as well as at multiple trophic levels and a variety of life-history stages (Raffaelli, 2006). Analyzing the importance of physico-chemical variability must be done at various spatial and temporal scales to determine which parameters and what scales truly affect organismal assemblages. Are rare, annual, or daily changes most critical? Most such studies have been done in estuaries with dramatic spatial and temporal variation in physical parameters, e.g. striking differences in grain size, or along a complete freshwater to marine salinity gradient (e.g., Hirst 2004). In a previous study (Dethier and Schoch 2005) we assessed community structure patterns using a hierarchical sampling design for 45 beaches in Puget Sound, Washington, a fjordal estuary with much more constrained physical gradients. We controlled several key variables by working only at one tidal 
height and only in pebble-sand beaches with no apparent pollution issues. Species richness increased steadily towards the mouth of the estuary, correlated with shallow gradients in nearshore wave energy, temperature, and salinity. However, we were unable to examine scales of variation of potentially key physical parameters, or actual parameters on the beach itself. Here we focus our studies on several sites spanning this gradient, testing 1) whether biomass of flora and fauna follow the same gradient as species richness, which could indicate a key role of trophic sources in controlling biotic parameters; 2) whether the general open-water physical gradients described earlier are overlain by higher spatial and temporal variation in these parameters on the shore, where the biota were studied, and 3) whether such variation correlates with patterns of richness and biomass. These data will serve as a physical backdrop for process studies on the roles of productivity, recruitment, and post-recruitment mortality in generating the diversity gradient in this system.

\section{STUDY SITES AND METHODS}

Puget Sound is a large, topographically complex fjordal estuary characterized by rivers that enter at numerous locations along its length, and by sills and constricted passages that promote mixing (Babson et al., 2006; Moore et al., 2008). Flow within the Sound is dominated by tidal currents; the tidal range is large, reaching $4.6 \mathrm{~m}$ at the southern (inner) end of the estuary. The Sound thus does not experience the large or unidirectional salinity gradients seen in simple or shallow estuaries, although there is more seasonal stratification and greater variation in temperature and salinity in the inner Sound than near the mouth (Moore et al., 2008). Greater gradients are seen in Hood Canal, an isolated branch to the west, and in shallow finger inlets in South Sound. All regions, especially near the mouths of the rivers nested within the Sound, show 
seasonal patterns in salinity and temperature, driven largely by high precipitation in winter and/or by snowmelt in late spring and summer.

Against this complex backdrop, we chose three of the sampling sites studied previously by Dethier and Schoch (2005) that spanned most $(83 \mathrm{~km})$ of the overall estuarine gradient: one site (Budd) in southern (inner) Puget Sound, one (Brown) in south-central, and one (Carkeek) in north-central (Fig. 1). Detailed studies were carried out in 2004-5 at 3 beaches nested within each of the sites; the 'replicate' beaches per site were within $3 \mathrm{~km}$ of each other along these rather linear, open shorelines. We chose this subset of our previous sites to: a) span as much of the Sound as possible, b) have 3 beaches that were reasonable "replicates" of each other in terms of substratum, c) have no known history of pollution or unpredictable physical disturbances such as waves of sand that bury the low shore, and d) be logistically accessible year-round. Use of more sites would have been desirable in this complex system, but the labor-intensive nature of our studies made this impossible.

To test whether there is a gradient in biomass of shoreline biota that parallels the gradient in species richness, in June 2004 and June 2005 we quantified tissue biomass of all macroscopic organisms in 5 randomly selected $0.3 \mathrm{~m}^{3}$ samples at each of the nine beaches. Samples were taken from a $50 \mathrm{~m}$ transect line laid parallel to the shore at mean lower low water (MLLW); this level was determined from tidal predictions over numerous dates. For surface flora and fauna, we picked off and bagged all algae, mobile invertebrates, and sessile invertebrates such as oysters from a $0.1 \mathrm{~m}^{2}$ quadrat. Percent cover of barnacles on cobbles was estimated and later converted to dry biomass based on separately calculated regressions of dry tissue mass $\mathrm{cm}^{-2}$ of live barnacles. This biomass value is conservative because barnacles on the sides of cobbles were not counted in percent cover estimates. Large infauna were quantified by digging up all sediment 
below the quadrat down to $30 \mathrm{~cm}$, and sieving on coarse $(1 \mathrm{~cm})$ mesh. Smaller infauna were sampled with 10 cores $(10 \mathrm{~cm}$ diam. $\mathrm{x} 15 \mathrm{~cm}$ deep) along the same transect, sieved to $2 \mathrm{~mm}$, and their biomasses converted to dried mass $0.3 \mathrm{~m}^{-3}$. Use of $2 \mathrm{~mm}$ sieves was necessary because smaller mesh sizes completely clog with this coarse pebble-sand sediment. All collected biota were sorted to species in the laboratory, removed from shells if necessary, counted, and dried to a constant weight. Species on these beaches and their trophic groups are listed in Dethier and Schoch (2005). Differences in biomass values were tested with a 2-way nested ANOVA (Systat 9) with main effects of Year and Site, and between-subjects error of Beaches nested within Site.

We examined physical data from throughout the year because the macroscopic flora and fauna we sampled each June constitute an integrated picture of the organisms that have managed to survive over the previous months. Preliminary data suggested that temperature varies substantially in both space and time on these beaches, so we used temperature dataloggers (TidbiT, Onset Computer Corp.) to gather fine-scale data. At each of the nine beaches, TidbiTs were attached to PVC pipes and installed in May 2004 in three habitats: on the surface of the sediment at MLLW (to quantify temperature variation for surface flora and fauna); ca. $5-8 \mathrm{~cm}$ beneath the sediment surface at MLLW (to quantify porewater temperatures experienced by infauna); and above the sediment surface near extreme low water (to quantify nearshore water temperatures). All TidbiTs logged temperatures every $40 \mathrm{~min}$ for up to 15 months. Data used in analyses were maximum/day, average/day, and change in temperature/day for each TidbiT. Weekly averages were calculated for some parameters. When TidbiTs were lost from some habitats at some beaches, data were pooled among beaches per site.

There are no similar inexpensive loggers with long battery lives for recording variation in the key parameter of salinity. Thus our salinity data are confined to periodic recordings using 
a YSI Salinity Conductivity Temperature meter (model 30/10 ET). To measure seasonal changes in the nearshore water, in 2004-5 we took readings every 1-2 months from a boat ca. $5 \mathrm{~m}$ offshore. To measure interannual and local (within a beach) variation in porewater, in June of 2001, 2004, 2005, and 2006 we recorded porewater salinity in three randomly selected holes dug at MLLW in each beach.

Finally, although our beaches were chosen from a set of sites with similar pebble-sand surface sediments, we quantified grain sizes because of the importance of this parameter to shoreline biota. We also were interested in the extent of seasonal yariability in grain sizes, since these sites experience considerable wintertime wave action. In April, July, and December 2005, we collected five replicate samples of $120-150 \mathrm{ml}$ (to ca. $6 \mathrm{~cm}$ depth) of sediment at each beach, removing live organisms, shells, and pebbles larger than $\sim 3 \mathrm{~cm}$. Samples were placed in a drying oven at $\sim 60^{\circ} \mathrm{C}$ until completely dried, then hand-sieved through $2 \mathrm{~mm}$ and $1 \mathrm{~mm}$ sieves. We weighed $60-100 \mathrm{~g}$ of the fine sand $(<1 \mathrm{~mm})$, placed it in a muffle furnace for $6 \mathrm{~h}$ at $500^{\circ} \mathrm{C}$ to burn off organics, then cooled and reweighed it. The ashed dry sample was then sieved on a standard sieve series for 6 min with a Ro-tap shaker, and each portion weighed. Grain size fractions were analyzed as "species" in PRIMER multidimensional scaling plots to look for variation in relative abundances of different size fractions at different beaches and dates.

\section{RESULTS}

\subsection{Biotic Patterns}

As in our previous, broader surveys of pebble-sand beaches throughout the Sound (Dethier and Schoch 2005), a clear pattern of higher species richness in the outer-Sound (more marine) beaches was seen in the samples collected for biomass measurements in both 2004 and 2005 (Fig. 2A). Almost twice as many species are found on beaches in the outer than in the inner 
Sound, and this pattern can be seen in virtually all trophic groups. No clear patterns are seen within sites, i.e. between the South (S), Middle (M), and North $(\mathrm{N})$ beaches in one region. In these surveys, the richness at Brown is not higher than at Budd, but it distinctly was in our previous study which used more replicate samples per beach (Dethier and Schoch 2005). The richness pattern is not driven by rare taxa; even though species found as only 1 or 2 individuals per transect made up over one third of the richness per beach, the proportion of rare taxa shows no trend along the estuarine axis (unpubl. data). Some interannual variation was seen, e.g. at Carkeek N where richness was much lower in 2004 than expected; the species 'missing' in that year included various deposit feeders (some polychaetes and the clam Macoma inquinata) and omnivores (such as crabs and isopods), but these were seen in 2005 as well as in the other Carkeek beaches.

Biomass of organisms showed a parallel pattern of being greater in the outer beaches and being quite consistent among years. Figure 2B shows this trend with two major biomass components removed to illustrate that they do not drive the pattern. Ulvoid algae are abundant on many beaches but are ephemeral and patchy; they showed no trends along the estuarine axis, and removing their biomass (average $8.1 \mathrm{~g}$ dry in 2005) makes it possible to see patterns in the less ephemeral primary producers (other macroalgae). Large edible clams were also removed from the analysis, again because their biomass numbers swamped those of other suspension feeders (average $14.6 \mathrm{~g}$ biomass, but ranging from 0 to $117 \mathrm{~g}$ per sample). In addition, because they are sometimes harvested recreationally, differential digging at the sites could bias natural biomass patterns. If clam data are included, the trend is even more obvious, because clams were much more abundant in the outer beaches (all the samples with over $25 \mathrm{~g}$ clam tissue were at Carkeek). Total biomass varied significantly among sites (2-way ANOVA on log-transformed data, $\mathrm{F}=$ 
$24.28,2$ d.f., $p=0.001$, all pairwise comparisons significant) and was marginally higher in 2004 $(\mathrm{F}=3.68,1$ d.f., $\mathrm{p}=.10)$. Beaches within sites were also variable (beaches nested in sites, $\mathrm{F}=$ 2.89, 6 d.f., $\mathrm{p}=0.014)$. All individual trophic components except for deposit feeders likewise showed significant site effects, with the trend always Budd $<$ Brown $<$ Carkeek. Figure $2 \mathrm{C}$ shows the full biomass including ulvoids and large clams, with the data pooled into surface organisms (flora and fauna) versus infauna. A trend of increasing mass towards the outer estuary can be seen in both groups.

\subsection{Abiotic Conditions}

The background physical conditions for all beaches are set by those of the nearshore waters, which cover our sampled intertidal level (MLLW) ca. $90 \%$ of the time. Daily average temperatures of the nearshore waters over 15 months show predictable seasonal patterns but also distinct regional differences (Fig. 3A); Carkeek and Brown temperatures are virtually indistinguishable, but water adjacent to the 3 southernmost sites (Budd) gets distinctly warmer (by $\sim 2^{\circ} \mathrm{C}$ ) each summer than water adjacent to the central and northern sites. This difference disappears mid-winter as all temperatures reach their minima. These data are very similar to midchannel water temperatures (Moore et al. 2008), except for reaching slightly higher summer values.

Beach surface temperatures (Fig. 3B) reflect localized effects overlaid on the regional water temperature conditions. Daily averages show predictable seasonal patterns, peaking in July and August when higher air temperatures and midday low tides warm the beach surface above the temperature of the nearshore waters. Average minima occur in February when ambient air is coldest and low tides fall in the middle of the night. There is a consistent pattern for the innersound sites (Budd) to experience warmer daily average beach temperatures than the Brown or 
Carkeek sites by about $2^{\circ} \mathrm{C}$ each summer, and to be about $2^{\circ}$ higher than the nearshore water temperatures at those times (Fig. 3A).

Temperatures in the sediment (Fig. 3C) are affected by a complex mix of air and sun warming the beach surface, nearshore water rising and falling through the water table with the tide, and groundwater percolating down from the land. Sediment temperatures are consistently cooler than the beach surface but show almost identical patterns, both seasonally and in terms of the higher temperatures seen at the Budd beaches.

Potentially stressful temperature variation experienced on fine spatial and temporal scales is better illustrated in Figure 4, which shows the average daily maxima during the summer at each site (daily summer minima are equal to the nearshore water temperature, when the tide covers the beach). The higher temperatures at Budd for all 3 habitats are clearly visible, as is the contrast among habitats. Maximum temperatures at Budd beaches rise an average of approx. $3^{\circ}$ over ambient (nearshore) temperatures each day in the sediment and $6^{\circ}$ on the surface, and slightly smaller rises occur at Brown and Carkeek (Fig. 4). A two-way ANOVA on these data from all the functioning Tidbits (pooled per site) showed both a Site effect $(\mathrm{F}=98.72,2$ d.f., $\mathrm{p}<$ 0.001; Budd $>$ Brown $=$ Carkeek $)$ and a Habitat effect $(F=1157,2$ df, $\mathrm{p}<0.001$; nearshore $<$ sediment $<$ surface $)$ but no interaction $(\mathrm{p}=0.47)$.

No fine-scale (daily) salinity data are available to compare with the temperature data. Nearshore salinities measured adjacent to each beach every 1-2 months from June 2004 to Sept. 2006 were highly variable among sites and times (data not shown); all showed maxima of 30-32 psu, usually in late summer, and minima at irregular times, during periods of high rain (autumn) or snow melt (spring). Recorded minima were lower at Budd (23, 20, and 22 near the three beaches) than at Carkeek $(28,29$, and 28). Brown was intermediate $(24,24)$ except at Brown S, 
which experienced some very low values $($ e.g. 9,19$)$ because of its proximity to the mouth of the Puyallup River.

Salinity of the beach porewater during low tide measurements in June of each year showed substantial variability among the 3 holes per beach, the 3 beaches per site, and the 3 regions, as expected with such a 'snapshot' view. Figure 5 shows these data averaged over June observations from 2001, 2004, 2005, and 2006, and compared to the nearshore values adjacent to each beach. There was both a Site effect $(\mathrm{F}=5.661,2 \mathrm{df}, \mathrm{p}=0.005$; Brown $<$ Budd $=$ Carkeek $)$ and a Habitat effect $(\mathrm{F}=15.744,1 \mathrm{df}, \mathrm{p}<0.001$; Nearshore $>$ Porewater $)$ and no interaction. Porewater salinity showed no correlation with nearshore salinity measured at the same time $\left(r^{2}=\right.$ $0.07, \mathrm{~N}=40$ ); porewater values ranged from $7 \mathrm{psu}$ lower to $12 \mathrm{psu}$ higher. Interestingly, over the four years of June measurements, four beaches always had porewater salinities that were less than the nearshore water, presumably affected by seeping groundwater. One beach, Brown S, always had higher porewater salinity, presumably because of the pulses of riverine influence on the nearshore water. The other four beaches varied from date to date.

The differing physical regimes experienced by the nearshore waters vs. the beach are illustrated by different correlations between temperature and salinity. In the nearshore waters, there is a weak negative correlation among sites between temperature and salinity (June data; $\mathrm{r}^{2}$ $=0.24, \mathrm{p}=.016)$; the outer-estuarine sites, influenced by oceanic water coming in through the Strait of Juan de Fuca (Fig. 1), are cooler and more saline than the inner sites. In the beach porewater from June, however, there is a positive correlation - cooler temperatures are associated with lower salinities $\left(\mathrm{r}^{2}=0.34 . \mathrm{p}<0.001\right)$. This pattern may be driven by rain or snowmelt in the watershed delivering cooler and less saline groundwater to the beach. 

over all beaches and dates; in general, the winter samples were characterized by fewer pebbles and more sand, as sand moved onto the low shore in winter storms. There was no overall trend along the estuarine axis in coarse sediments, however; rather, each beach had a characteristic and persistent mix, with two of the Brown beaches being the most coarse. Figure 6B shows the relative abundances of just the finer grain sizes (summer data). All beaches were dominated by coarse to fine sands (Phi 1-3), with low proportions of fines and organics, and no gradient along the estuarine axis. When all the grain size fractions and dates were analyzed in Primer MDS plots, sites appeared as strongly separated (Global R for Sites $=0.45, \mathrm{p}=0.001)$, with Brown beaches being especially different from the other two sites. Seasons were much less well separated than sites (Global $\mathrm{R}$ for Dates $=0.07, \mathrm{p}=0.002$ ), with December significantly different from April and July.

\section{DISCUSSION}

Our results for pebble-sand beaches in the Puget Sound estuary show that there are distinct and persistent trends in biomass that parallel the previously described (Dethier and Schoch 2005) trend in species richness from the inner (more enclosed) end to the outer (more marine) end. The gradients in both parameters are towards much higher values at the marine end, unlike in some estuaries where diversity and biomass show opposite patterns (Giberto et al., 2004). In addition, there is no evidence that trophic diversity is higher at the mouth of the estuary; all trophic levels sampled (e.g. we did not sample large vertebrate predators) are represented along the whole gradient, but with more species in each level at the marine end (Fig. 2A). This implies that whatever broad process(es) cause low biodiversity in the inner portions of 
the Sound do not disrupt trophic function in this habitat type, i.e. that the food sources for these shoreline organisms are diverse. Targeted studies of growth rates of primary producers and suspension feeders at our sites show that they vary among species, suggesting that biomass patterns are not driven by consistently faster growth in the outer Sound (Ruesink et al. in review). The biomass gradient is also spatially large and is consistent in both epi- and infauna, suggesting that forcing mechanisms operate on a large scale (Edgar and Barrett, 2002) and affect both the surface and the sediment. The relative lack of interannual variability in biota also implies that the key processes are likely to be chronic, such as annual high summer temperatures, rather than temporally unpredictable (such as occasional defaunation events in some estuaries).

Dethier and Schoch (2005) described correlations of this trend in richness with physical characteristics of regional climate (air temperature and precipitation) and open water (mid-Sound sea surface temperature and salinity), but abiotic factors measured on local beaches were limited to surface sediment characteristics, estimates of wave power, and 'snapshot' summertime porewater temperatures and salinities. We found that physico-chemical conditions on the beach, i.e. those experienced by the shoreline flora and fauna, show variation at all temporal and spatial scales measured. Factors that vary on a site (or smaller) scale, such as local riverine influence and porewater salinity, are only poorly related to the large-scale patterns. Sediment grain sizes also show no patterns along the estuarine axis, but rather beach-specific characteristics that vary somewhat with season, and probably depend on local wave conditions and alongshore drift. Temperature and salinity encountered by the organisms on the beaches do covary with the biotic gradient, and are affected by variation from several sources. The backdrop is the nearshore water conditions, which affect all the sites and are slightly more variable in the inner Sound. Added to this is variation caused by ambient air conditions warming the beach surface; again, this leads to 
higher extremes in the inner Sound, primarily because low tides fall approximately $1 \mathrm{~h}$ later at those sites than at our outer ones, i.e. into the warmer part of the day during spring and summer daytime low tides. Temperatures may also reach colder extremes in the winter in the inner Sound when low tides are at night, but this signal was harder to detect. Epibiota on the beach surface encounter these more variable conditions. Finally, greater warming of the upland surface and greater rainfall in the inner Sound (Dethier and Schoch 2005) can affect groundwater conditions that impact the beach during low tide, when the marine water table is low. These fluctuations in groundwater properties, compounded by variation on the beach surface that propagates into the sediment, will especially impact infauna.

Does the physical variation in Puget Sound beaches provide a mildly stressful background condition, or is it actually important to the composition of the biota? Work in other estuaries (references in Introduction) has often drawn conclusions about the key roles of salinity and sediment type based largely on correlative evidence, either simple linear correlations or complex multivariate analyses. It is harder to determine, however, whether low or variable salinity (for example) actually causes low diversity in upper estuaries, and if so via what mechanism. Recent evidence (including field observations and lab experiments) suggest that the range of a factor, especially salinity, and the time span over which that range occurs, is more important to organisms than the absolute minima (Attrill, 2002; Hirst and Kilpatrick, 2007; McLeod and Wing, 2008). Acclimation to seasonal changes in salinity and temperature is likely to take weeks (Dame, 1996), so that short-term variation may exceed physiological tolerances, or at least negatively affect growth or reproduction (Beukema et al., 2009). To affect an integrative pattern such as richness, however, a parameter must consistently cause mortality at some life stage of multiple species; studying such effects at the community level is challenging. 
If physical stresses are a significant cause, rather than just a correlate, of the lower diversity and biomass in the inner portions of Puget Sound, the most striking pattern here is the large magnitude of the biotic gradients relative to the small magnitude of the physical ones. While grain size correlates with diversity in other estuaries (e.g., Mannino and Montagna 1997), we largely controlled for this factor by only working in one beach type (pebble-sand) rather than the broad range (silt to sand or pebbles) studied elsewhere. Similarly, nearshore salinity appeared to affect the biota even though the range at our sites was only on the order of 22-32 psu, a far more subtle gradient than the 5-28 or even 0-40 psu differences noted as important to infauna in other estuaries (Rutger and Wing 2006; Rakocinski et al. 2000, respectively). However, mechanisms behind the roles of salinity or temperature stressors in Puget Sound may well involve extreme events not captured by our sampling; and with predictions that extreme weather events may become more common in the future (Cardoso et al., 2008), such mechanisms will become increasingly important. As in most estuaries (Dame, 1996), combinations of temperature and salinity extremes may affect organisms more than just the sum of their individual stress effects.

Many previous studies along estuarine gradients have investigated subtidal rather than intertidal biota, and thus factors such as moisture retention and temperature variation in the sediment have not been considered. These issues have received attention in the growing geomorphological literature about the shoreline water table, especially on sandy beaches (Jackson et al., 2002; Li et al., 2006), but have seldom been related directly to their impacts on beach biota. Several recent studies have shown that local groundwater characteristics, especially low-salinity seeps, can significantly affect flora and fauna (Dale and Miller, 2008; Rumrill and Sowers, 2008; Zipperle and Reise, 2005) and thus behavior of predators such as birds (Rosa et 
al., 2007). The shorelines of Puget Sound are mostly backed by bluffs of glacial deposits (as illustrated in Jackson et al. 2002); erosion of these leads to beaches that are a mix of many sediment types. The beaches studied here and that are characteristic of most of the estuary's open shorelines are exposed to waves that remove the fine sediments (Fig. 6B), leaving relatively coarse substrates at all tidal elevations. Hydraulic conductivity of such coarse beaches is high, meaning that the marine water table drains relatively rapidly at low tide compared with mud beaches (Dale and Miller, 2008). The level of the water table, in turn, has significant impacts on factors important to infauna such as temperature and moisture content (Dale and Miller, 2008; Jackson et al., 2008; Li et al., 2006). In our study, elevation was constant among beaches but the moisture content clearly varied, as evidenced by the rate of filling of holes dug for porewater measurements (one of the Brown beaches was usually dry when sampled, for example); this variation could be due to hydraulic conductivity of the beach and/or to the amount of groundwater percolating down from the land. Most of the beaches studied are bulkheaded, as are approximately half of the open shorelines of central and southern Puget Sound, but this did not seem to affect the passage of groundwater (as suggested by Plant and Griggs 1992).

Potentially important factors that were not included in our analyses of the drivers of diversity patterns are levels of anthropogenic disturbance (e.g., bulkheading of the shore; see Seitz et al. 2006) and biotic factors such as nutrient sources, dispersal, recruitment, competition, and predation. Food sources can affect growth rates and therefore biomass, although connections to diversity are less direct. Physical variables affecting dispersal to and recruitment at each site, and post-recruitment survival, may be critical (Jackson et al., 2008; McLeod and Wing, 2008). These could provide the mechanisms underlying the processes that correlated with diversity; for example, sand cover may not directly drive diversity trends, but sand burial could affect post- 
recruitment survival. Disentangling these diverse physical and biological processes, which covary, is a challenge and is the focus of ongoing experimental work.

\section{CONCLUSIONS}

Variation in physical parameters on estuarine shorelines in Puget Sound is quite low compared to many other estuaries, but particular parameters nonetheless correlate with strong gradients in species richness and biomass. Temperatures, salinities, and grain sizes on studied beaches vary among seasons, beaches, and regions; parameters that most closely match the estuarine-marine biotic gradients in the Sound are the temperatures on the beach itself, and the open-water salinity that bathes the beaches at high tide. The relatively minor changes in daily and annual values of these physical parameters raise the question of whether they are directly, indirectly, or not at all responsible for the biotic patterns seen.

\section{ACKNOWLEDGEMENTS}

This project could never have been accomplished without field assistance from many people, including Aaron Galloway and numerous DNR and UW volunteers. Carl Schoch generously gave input at many levels. Space and use of facilities at the Friday Harbor Laboratories were provided by the Director. This research was funded in part by a grant from the Washington Sea Grant Program, University of Washington, pursuant to National Oceanic and Atmospheric Administration Award No. R/ES-57. The views expressed herein are those of the authors and do not necessarily reflect the views of NOAA or any of its sub-agencies. Matching funds were generously provided by the Washington Dept. of Natural Resources. 


\section{REFERENCES}

Anderson, M.J., Ford, R.B., Feary, D.A. and Honeywill, C., 2004. Quantitative measures of sedimentation in an estuarine system and its relationship with intertidal soft-sediment infauna. Marine Ecology Progress Series 272, 33-48.

Attrill, M.J., 2002. A testable linear model for diversity trends in estuaries. Journal of Animal Ecology 71, 262-269.

Babson, A.L., Kawase, M. and MacCready, P., 2006. Seasonal and interannual variability in the circulation of Puget Sound, Washington: a box model study. Atmosphere-Ocean 44, 2945.

Beukema, J.J., Dekker, R. and Jansen, J.M., 2009. Some like it cold: populations of the tellinid bivalve Macoma balthica (L.) suffer in various ways from a warming climate. Marine Ecology Progress Series 384, 135-145.

Bishop, M.J., Powers, S.P., Porter, H.J. and Peterson, C.H., 2006. Benthic biological effects of seasonal hypoxia in a eutrophic estuary predate rapid coastal development. Estuarine, Coastal and Shelf Science 70, 415-422.

Cardoso, P.G., Raffaelli, D., Lillebo, A.I., Verdelhos, T. and Pardal, M.A., 2008. The impact of extreme flooding events and anthropogenic stressors on the macrobenthic communities' dynamics. Estuarine, Coastal and Shelf Science 76, 553-565.

Currie, D.R. and Small, K.J., 2005. Macrobenthic community responses to long-term environmental change in an east Australian sub-tropical estuary. Estuarine, Coastal and Shelf Science 63, 315-331.

Dale, R.K. and Miller, D.C., 2008. Hydrological interactions of infaunal polychaetes and intertidal groundwater discharge. Marine Ecology Progress Series 363, 205-215. 
Dame, R.F., 1996. Ecology of Marine Bivalves: an Ecosystem Approach. CRC Marine Science Series. CRC Press, Boca Raton, 254 pp.

Dethier, M.N. and Schoch, G.C., 2005. The consequences of scale: assessing the distribution of benthic populations in a complex estuarine fjord. Estuarine, Coastal and Shelf Science $62,253-270$.

Edgar, G.J. and Barrett, N.S., 2002. Benthic macrofauna in Tasmanian estuaries: scales of distribution and relationships with environmental variables. Journal of Experimental Marine Biology and Ecology 270, 1-24.

Giberto, D.A., Bremec, C.S., Acha, E.M. and Mianzan, H., 2004. Large-scale spatial patterns of benthic assemblages in the SW Atlantic: the Rio de la Plata estuary and adjacent shelf waters. Estuarine, Coastal and Shelf Science 61, 1-13.

Hawkins, S.J., 2004. Scaling up: the role of species and habitat patches in functioning of coastal ecosystems. Aquatic Conservation: Marine and Freshwater Ecosystems 14, 217-219.

Hernandez-Arana, H.A., Rowden, A.A., Attrill, M.J., Warwick, R.M. and Gold-Bouchot, G., 2003. Large-scale environmental influences on the benthic macroinfauna of the southern Gulf of Mexico. Estuarine, Coastal and Shelf Science 58, 825-841.

Hewitt, J.E., Anderson, M.J. and Thrush, S.F., 2005. Assessing and monitoring ecological community health in marine systems. Ecological Applications 15, 942-953.

Hirst, A.J., 2004. Broad-scale environmental gradients among estuarine benthic macrofaunal assemblages of south-eastern Australia: implications for monitoring estuaries. Marine and Freshwater Research 55, 79-92. 
Hirst, A.J. and Kilpatrick, R., 2007. Spatial and temporal variation in the structure of estuarine macroinvertebrate assemblages: implications for assessing the health of estuaries. Marine and Freshwater Research 58, 866-879.

Jackson, N.L., Nordstrom, K.F. and Smith, D.R., 2002. Geomorphic-biotic interactions on beach foreshores in estuaries. Journal of Coastal Research SI 36, 414-424.

Jackson, N.L., Smith, D.R. and Nordstrom, K.F., 2008. Physical and chemical changes in the foreshore of an estuarine beach: implications for viability and development of horseshoe crab Limulus polyphemus eggs. Marine Ecology Progress Series 355, 209-218.

Li, L., Horn, D.P. and Baird, A.J., 2006. Tide-induced variations in surface temperature and water-table depth in the intertidal zone of a sandy beach. Journal of Coastal Research 22, $1370-1381$.

Livingston, R.J., Niu, X., Lewis, F.G., III and Woodsum, G.C., 1997. Freshwater input to a gulf estuary: long-term control of a trophic organization. Ecological Applications 7, 277-299.

Mannino, A. and Montagna, P.A., 1997. Small-scale spatial variation of macrobenthic community structure. Estuaries 20, 159-173.

McLeod, R.J. and Wing, S.R., 2008. Influence of an altered salinity regime on the population structure of two infaunal bivalve species. Estuarine, Coastal and Shelf Science 78, 529540.

Mittelbach, G.G., Scheiner, S.M. and Steiner, C.F., 2003. What is the observed relationship between species richness and productivity? Reply. Ecology 84, 3390-3395.

Moore, S.K., Mantua, N.J., Newton, J.A., Kawase, M., Warner, M.J. and Kellogg, J.P., 2008. A descriptive analysis of temporal and spatial patterns of variability in Puget Sound oceanographic properties. Estuarine, Coastal and Shelf Science 80(545-554). 
Plant, N.G. and Griggs, G.B., 1992. Interactions between nearshore processes and beach morphology near a seawall. Journal of Coastal Research 8, 183-200.

Raffaelli, D., 2006. Biodiversity and ecosystem functioning: issues of scale and trophic complexity. Marine Ecology Progress Series 311, 285-294.

Rakocinski, C.F., Brown, S.S., Gaston, G.R., Heard, R.W., Walker, W.W. and Summers, J.K., 2000. Species-abundance-biomass responses by estuarine macrobenthos to sediment chemical contamination. Journal of Aquatic Ecosystem Stress and Recovery 7, 201-214.

Rosa, S., Granadeiro, J.P., Cruz, M. and Palmeirim, J.M., 2007. Invertebrate prey activity varies along the tidal cycle and depends on sediment drainage: consequences for the foraging behaviour of waders. Journal of Experimental Marine Biology and Ecology 353, 35-44.

Ruesink, J.L., Dethier, M.N., Trimble, A.C., Berry, H. and Sprenger, A.G., in review. Variation in trophic support of benthic intertidal production at multiple scales along an estuarine fjord. Estuaries and Coasts.

Rumrill, S.S. and Sowers, D.C., 2008. Concurrent assessment of eelgrass beds (Zostera marina) and salt marsh communities along the estuarine gradient of the South Slough, Oregon. Journal of Coastal Research SI(55), 121-134.

Rutger, S.M. and Wing, S.R., 2006. Effects of freshwater input on shallow-water infaunal communities in Doubtful Sound, New Zealand. Marine Ecology Progress Series 314, 3547.

Seitz, R.D., Lipcius, R.N., Olmstead, N.H., Seebo, M.S. and Lambert, D.M., 2006. Influence of shallow-water habitats and shoreline development on abundance, biomass and diversity of benthic prey and predators in Chesapeake Bay. Marine Ecology Progress Series 326, $11-27$. 
Wieser, W., 1959. The effect of grain size on the distribution of small invertebrates inhabiting the beaches of Puget Sound. Limnology and Oceanography 4, 181-194.

Wolff, W.J., 1983. Estuarine benthos. In: B.H. Ketchum (Editor), Ecosystems of the World 26: Estuaries and Enclosed Seas. Elsevier, Amsterdam, pp. 151-182.

Zipperle, A. and Reise, K., 2005. Freshwater springs on intertidal sand flats cause a switch in dominance among polychaete worms. Journal of Sea Research 54, 143-150. 


\section{FIGURE CAPTIONS}

Fig. 1. Map of the 3 study sites (Budd, Brown, and Carkeek) in Puget Sound.

Fig. 2. Data from biomass samples taken at the 9 beaches in 2004 and 2005; each site has 3 beaches nested within it: South (S), Middle (M), and North (N). A. Species richness in these samples, divided by trophic categories. Other $=$ carnivores and scavengers, Susp $=$ suspension feeders, Dep $=$ deposit feeders, Herb $=$ herbivores, and Prim $=$ primary producers (algae). B. Biomass (average per beach) divided by trophic categories, with two disproportionately large taxa removed (see text). C. Biomass including all taxa, categorized by surface vs. infaunal taxa.

Fig. 3. Temperatures from 3 sets of TidbiT dataloggers at each beach. Points are weekly averages of the average value per TidbiT per day. Sediment TidbiTs (panel C) were removed earlier than the other sets.

Fig. 4. Temperature extremes reached at each of the 3 sites during May-August (2004 and 2005). Each bar is the mean ( 1 s.e.) temperature from $\mathrm{N}=311-598$ daily-maximum points per site (beaches within sites pooled: not all loggers were functioning on all dates).

Fig. 5. Salinities in nearshore waters and porewater averaged over 4 June sampling dates. Bars are means and one s.d. For each date and beach, the salinity from the 3 holes per beach were pooled, then the averages of these pooled values taken over 4 years.

Fig. 6. Sediment grain sizes at all 9 beaches. A. Ratio by mass of coarse $(>1 \mathrm{~mm})$ to fine $(<1$ $\mathrm{mm}$ ) sediments during 3 seasons. Bars are one s.d. The error bar for Brown M in April was cut off to clarify the rest of the plot (s.d. = 1.2). B. Proportion of fine $(<1 \mathrm{~mm})$ sediments in each size class in July 2006. 


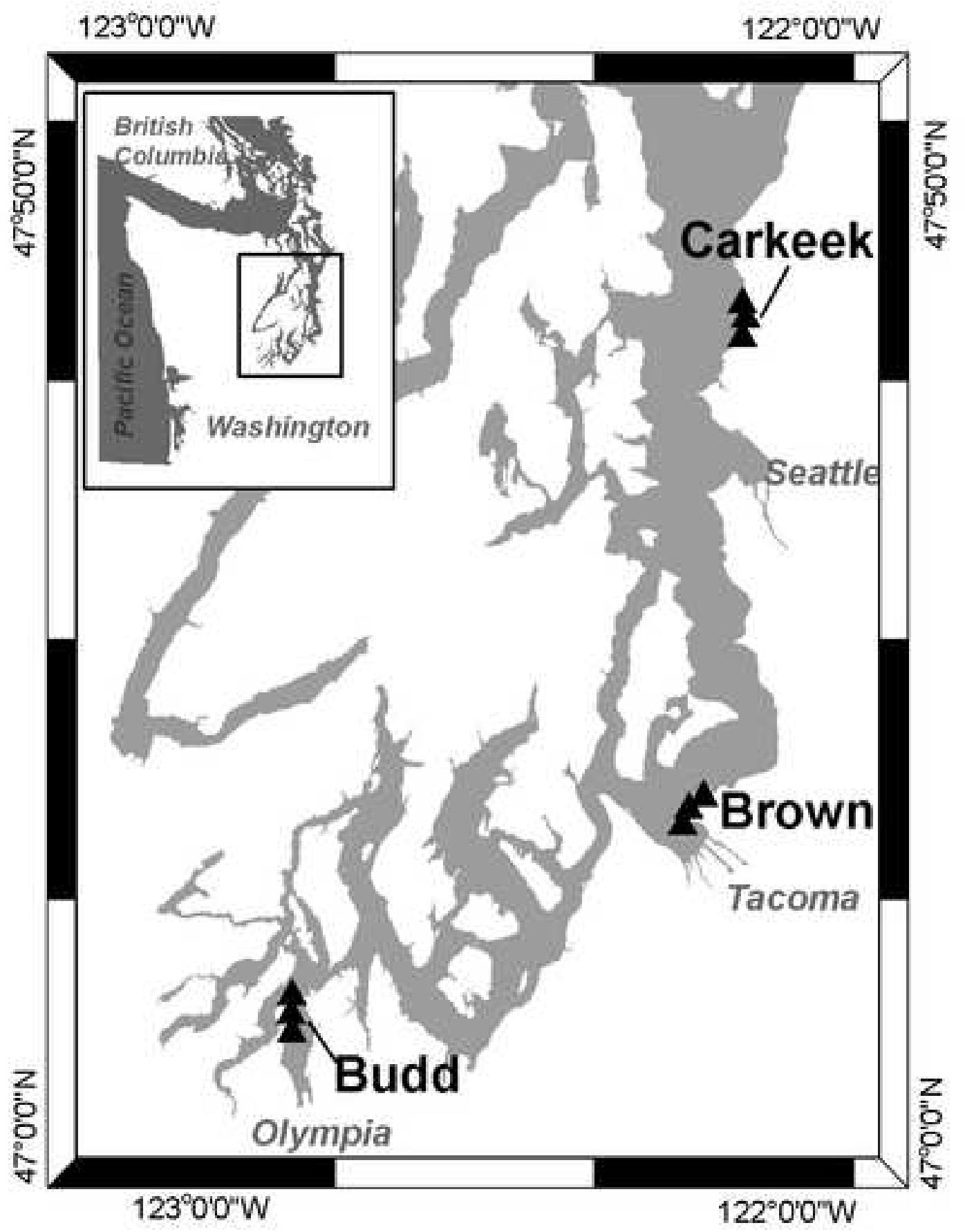


Figure 2.
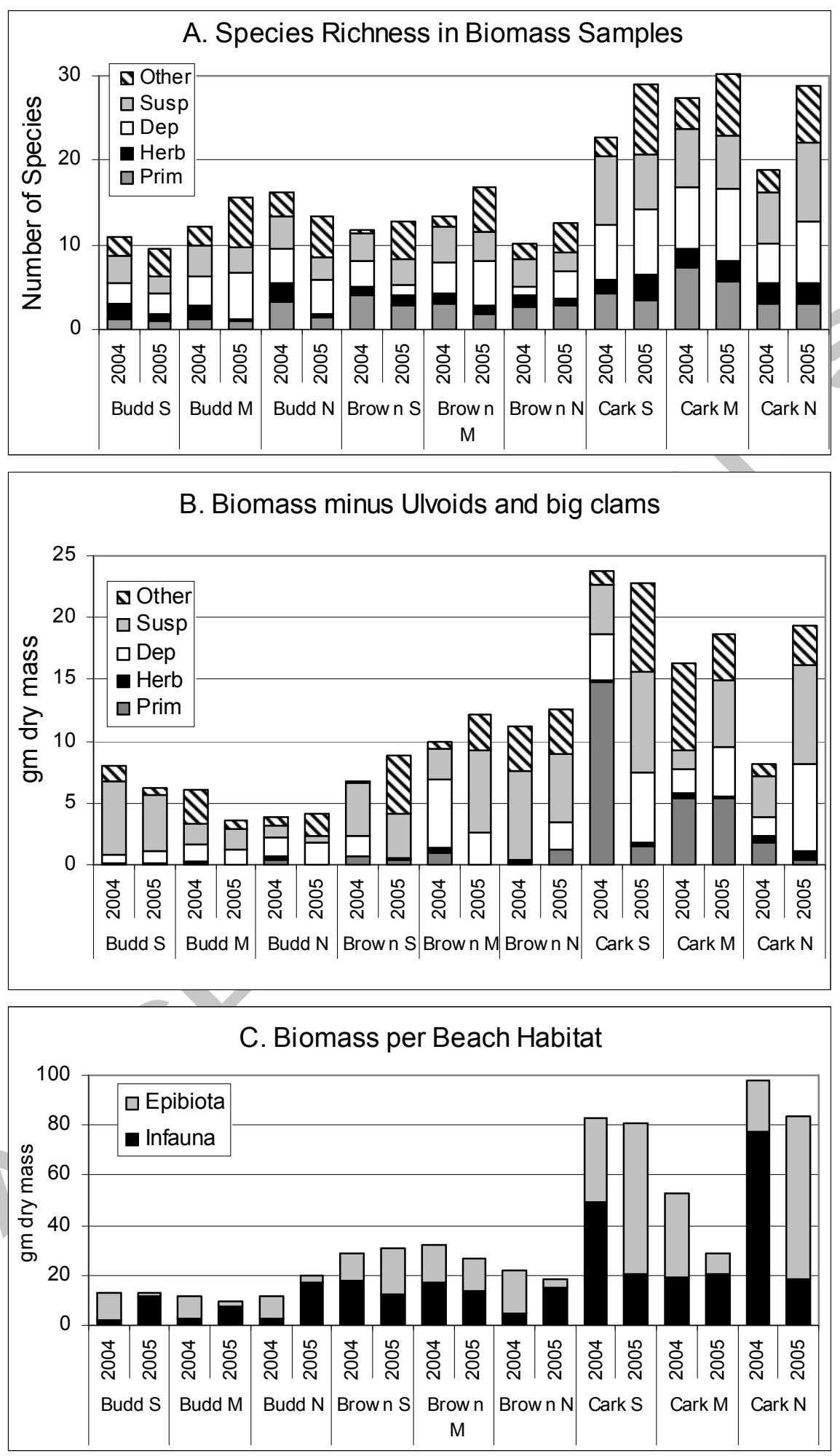
Dethier-2

Figure 3.
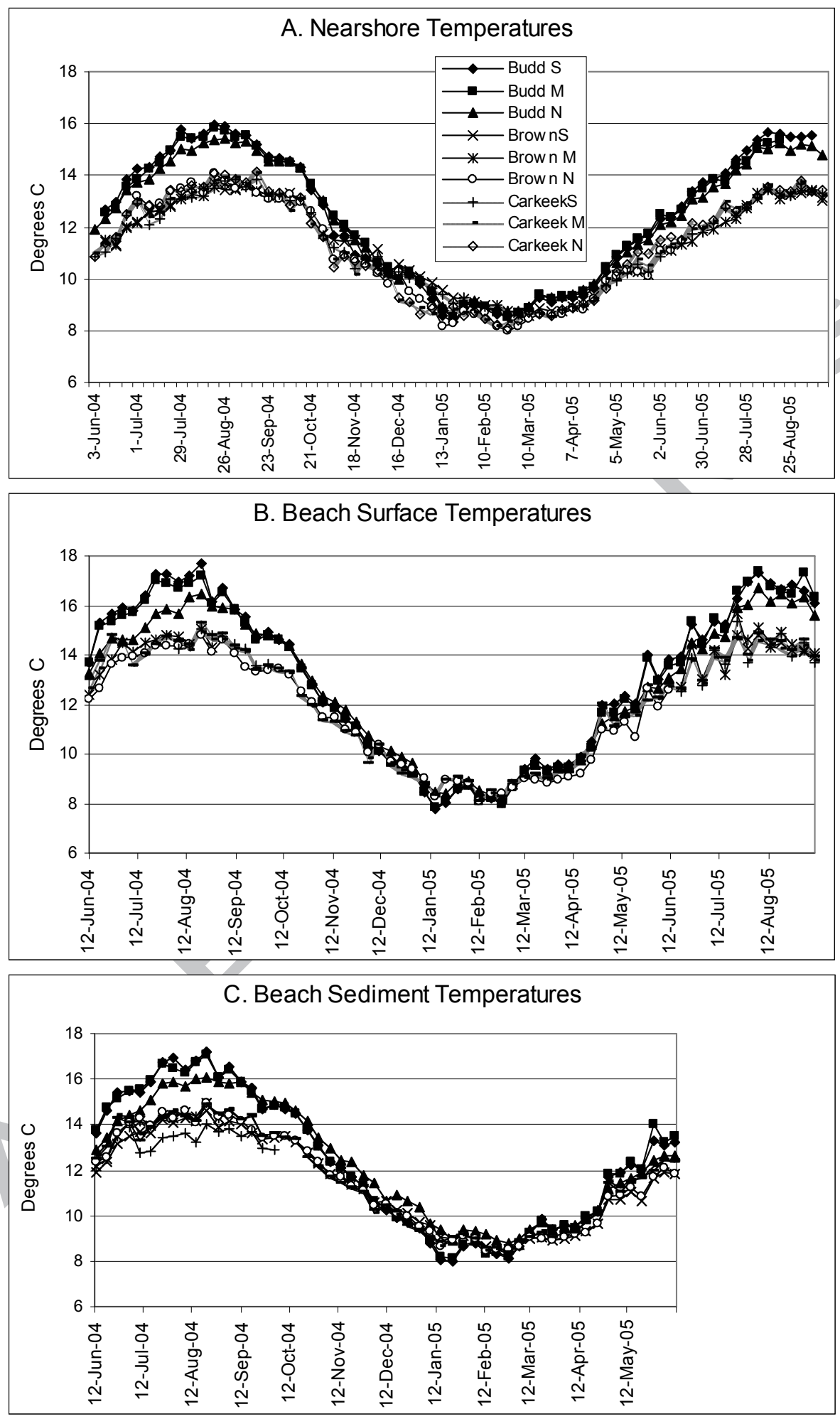
Figure 4.

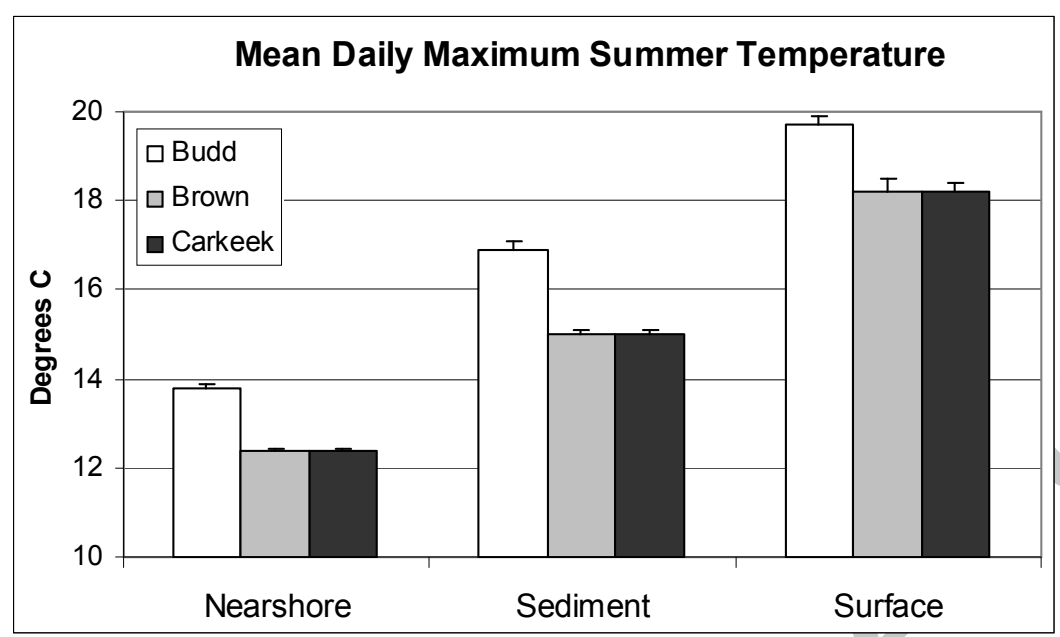


Figure 5.

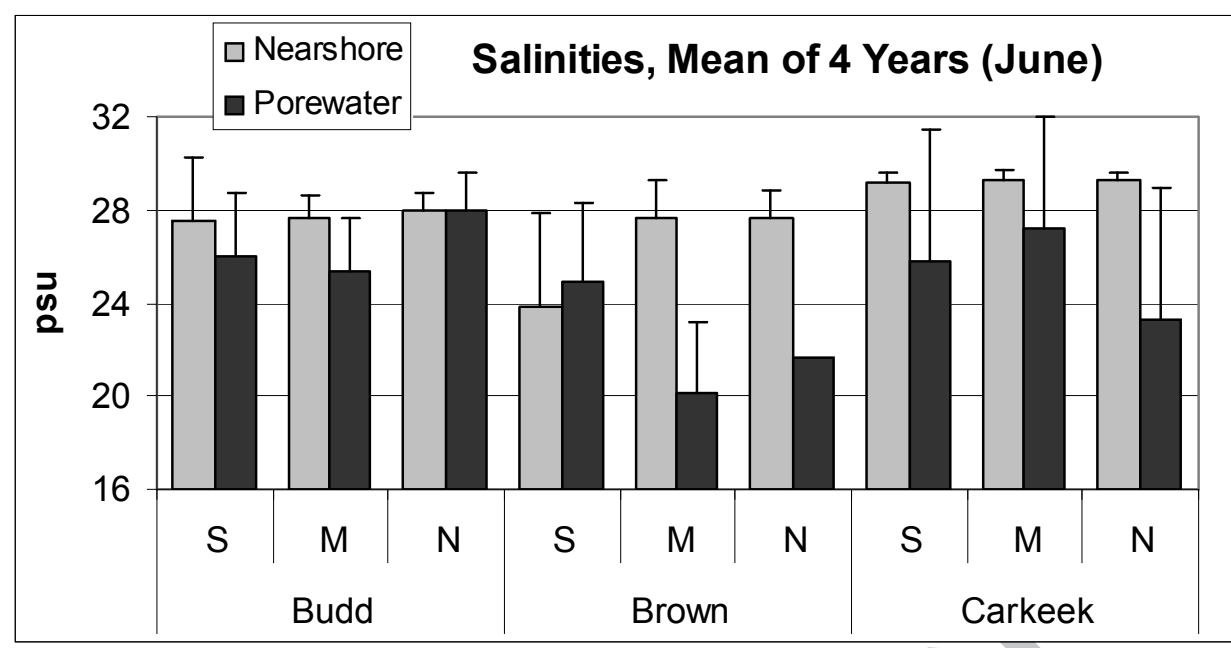


Dethier-5

Figure 6.
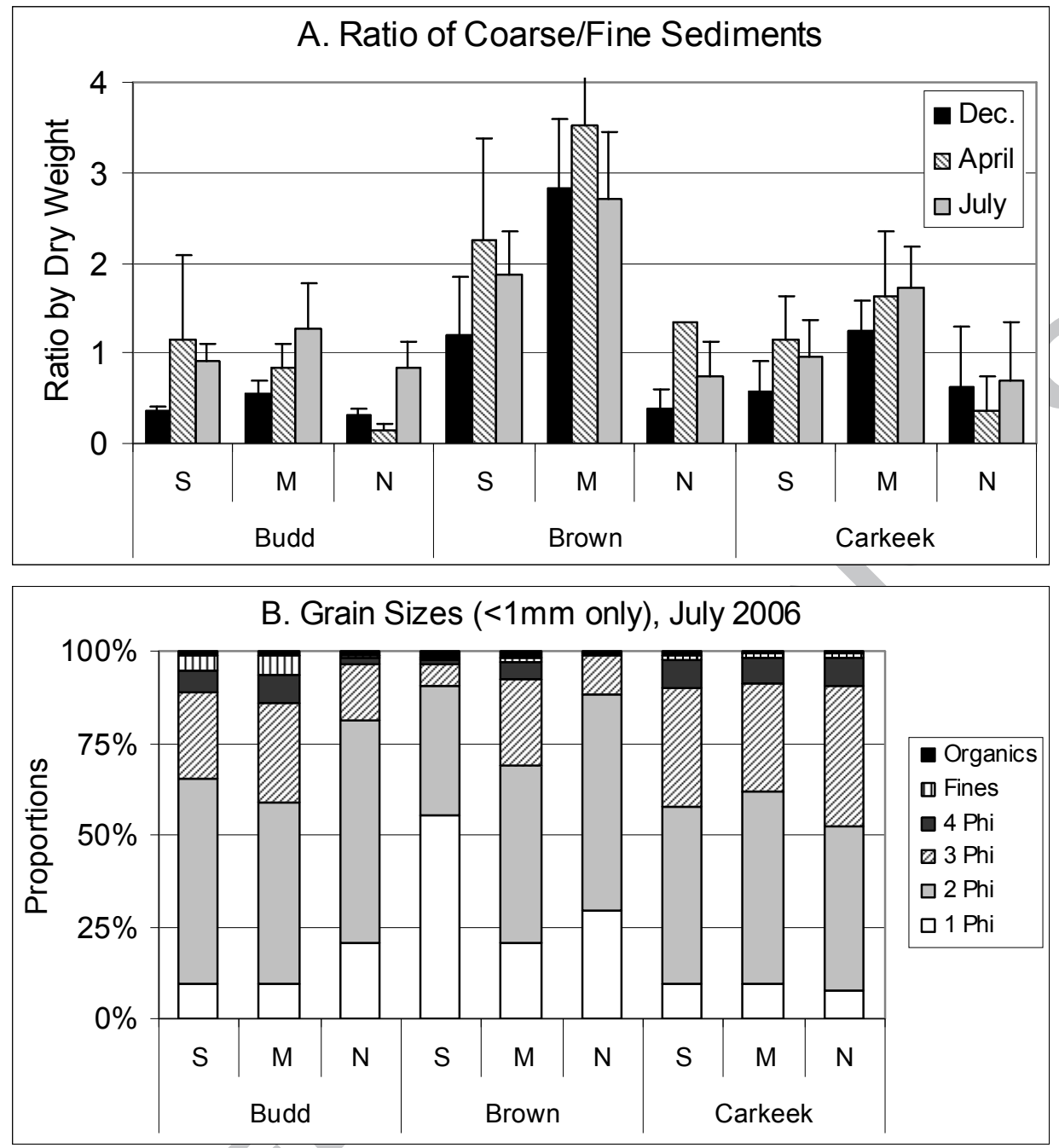